\title{
Multiplex qPCR Assay for Direct Detection and Quantification of Colletotrichum truncatum, Corynespora cassiicola, and Sclerotinia sclerotiorum in Soybean Seeds
}

\author{
Maísa Ciampi-Guillardi, Juliana Ramiro, Maria Heloisa Duarte de Moraes, Marina Coan Goldoni Barbieri, and Nelson S. Massola Jr. ${ }^{\dagger}$ \\ Department of Plant Pathology and Nematology, ESALQ, University of São Paulo, Piracicaba/SP, Brazil
}

\begin{abstract}
Precise diagnosis of plant diseases is one of the most effective tools to minimize yield losses. Colletotrichum truncatum, Corynespora cassiicola, and Sclerotinia sclerotiorum are common soilborne pathogens that affect soybeans all over the world. We developed a multiplex quantitative real-time polymerase chain reaction (qPCR) assay to simultaneously detect and quantify the three pathogens in soybean seeds and to survey their occurrence in the main soybean production areas in Brazil. Speciesspecific primers and probes for $C$. truncatum and $C$. cassiicola were designed based on GAPDH and TEF1 genes, respectively, to be com-

internal control. The four pathogens were detected and quantified in artificially and naturally infested soybean seeds, even in the lowest incidence level tested of $0.0625 \%$ or 1 infected seed out of 1,599 healthy ones. From 81 seed samples tested, $C$. truncatum was the most frequently detected pathogen and with higher incidence levels ( 0.25 to $0.125 \%)$, followed by $S$. sclerotiorum and C. cassiicola, both with lower incidence levels $(0.125$ to $0.0625 \%)$. Together, the results evidenced the high sensitivity of the multiplex qPCR assay, indicating its usefulness for a quick and reliable diagnosis of soybean diseases in seeds.
\end{abstract} bined with qPCR detection of $S$. sclerotiorum previously reported. The multiplex qPCR assay was successful in the simultaneous detection of C. truncatum, C. cassiicola, and S. sclerotiorum, along with a host
Keywords: anthracnose, target spot, white mold, molecular diagnosis, seed sanitation, fungal diseases
Soybean is one of the most important crops worldwide, especially for protein meal and oil production (Hartman et al. 2011). Soybeans are considered one of the main agricultural commodities, with great economic importance at global and national levels. In 2018, global soybean production exceeded 350 million metric tons, of which $85.8 \%$ was produced in the Americas, with the United States, Brazil, and Argentina as the largest producers (USDA 2019). In Brazil, soybean cultivation has increased yearly, in both area and yield. In the crop season 2017 to 2018, harvest was 117 million metric tons in a planted area of 35.9 million hectares (CONAB 2019; USDA 2019).

The occurrence of diseases in soybean crops is one of the factors that most affect its productivity and can cause considerable losses, by directly reducing seed yields or quality. Seedborne pathogens can be retained in seed lots as well, which can provide a substantial boost to their spread (Mancini et al. 2016). Due to our dependence on the soybean crop both directly and indirectly for food products, significant losses in soybean may have implications for food security (Hartman et al. 2011). The importance of these diseases varies annually, depending on the climate, the susceptibility of the cultivars, and the occurrence and spread of certain pathogens. Among the pathogenic fungi that could be seed-transmitted, Colletotrichum truncatum, Corynespora cassiicola, and Sclerotinia sclerotiorum have threatened soybean crops in the last decade (Allen et al. 2017; Godoy 2015; Willbur et al. 2019).

${ }^{\dagger}$ Corresponding author: N. S. Massola Jr.; nmassola@usp.br

Funding: This research was supported by grants from Fundação de Amparo à Pesquisa do Estado de São Paulo (2013/16726-0) and Conselho Nacional de Desenvolvimento Científico e Tecnológico (307320/2015-4). This study was financed in part by the Coordenação de Aperfeiçoamento de Pessoal de Nível Superior - Brasil (CAPES) - Finance Code 001.

*The $\boldsymbol{e}$-Xtra logo stands for "electronic extra" and indicates that two supplementary figures and one supplementary table are published online.

The author(s) declare no conflict of interest.

Accepted for publication 21 April 2020.

(C) 2020 The American Phytopathological Society
C. truncatum, associated with soybean anthracnose, is one important seedborne fungus pathogenic to soybean. Although the disease can affect the host at all developmental stages, it is most destructive in the reproductive stages (Yang and Hartman 2015). Under laboratory conditions, successful transmission of C. truncatum via infested soybean seed to seedlings occurred at high frequency, up to $99.5 \%$; when infected seeds are sown, seedlings might die before or shortly after emerging from the soil (Rogério et al. 2017). Infected seeds and crop residues are considered the initial sources of disease inoculum. A worldwide yield loss of 2.54 million metric tons was associated with anthracnose in the top eight soybean producing countries (Wrather et al. 2010); losses of $90 \mathrm{~kg} /$ ha of soybean grains were reported for each $1 \%$ increase in the anthracnose incidence in commercial crops in northern Brazil (Dias et al. 2016). Sharing of C. truncatum haplotypes across fields distant more than $800 \mathrm{~km}$ suggests a role of soybean seeds in the pathogen spread (Rogério et al. 2019).

The etiological agent of soybean target spot, $C$. cassiicola (Berk. and M.A. Curtis) C.T. Wei, can cause yield losses of up to $40 \%$ in soybean crops (Edwards Molina et al. 2018; Koenning and Creswell 2006). The pathogen survives on infected debris and seeds, favored by relative humidity of $80 \%$ and temperature range from 20 to $30^{\circ} \mathrm{C}$. It is mostly disseminated by rain splashes and infected seeds (Almeida et al. 2005; Godoy 2015). The disease was first reported in Brazil in the 1970s, and it is now found in all major Brazilian soybean producing regions due to no-till practices, sowing of susceptible cultivars, and reduced sensitivity to fungicides (Godoy 2015). In Brazil, because cotton is commonly cultivated in sequence with soybean, and both crops are affected by this same pathogen, there is great concern about planting pathogen-free seeds to reduce primary inoculum (Galbieri et al. 2014).

White mold, associated with the fungus $S$. sclerotiorum, is one of the most damaging soybean diseases worldwide (Grau and Hartman 2015). Lesions can affect the stem and block vascular flow, limiting pod and seed development. In the United States, the disease has significantly contributed to soybean yield reduction since 2000 (Allen et al. 2017; Willbur et al. 2019). In Brazil, it is estimated that a $10 \%$ increase in white mold incidence would cause soybean yield reduction of $172 \mathrm{~kg} / \mathrm{ha}$ and economic losses of about US $\$ 1.47$ billion per year (Lehner et al. 2017). Sclerotia, dark melanized resistance 
structures produced by the fungus, can overwinter in the soil or plant debris. The presence of sclerotia in seed batches could result in infection by the pathogen, which might reduce seed germination (Hoffman et al. 1998). Seeds are considered the main source of primary inoculum of white mold, whose management may only be partially achieved through fungicides and partial resistance (Hartman et al. 2011). Once introduced into the growing area, it becomes practically impossible to eradicate the pathogen. Thus, the best control measure is exclusion, avoiding its entry into production areas.

Movement of plant material may present a threat to diseases spread (Gergerich et al. 2015). Seeds are among the most important forms of long-distance survival and dissemination of plant pathogens (Sousa et al. 2016). Unlike infected vegetative plant tissues, infected seeds are in most cases symptomless; low percentages of seed infection may result in severe crop losses (Pellegrino et al. 2010), particularly if the pathogens are under quarantine. Legislation has been formulated to help limit or preventing pathogen introduction into new areas, generally supported by detection techniques. Additionally, pathogen populations on seeds may be low, and infested seeds may be nonuniformly distributed within a lot (Walcott 2003), making it difficult to test seeds for the presence of pathogens.

Convenient and precise diagnosis of plant diseases is one of the most effective tools to minimize yield losses. As usually infected seeds appear symptomless, early diagnosis of pathogens in seeds has great importance, because it could avoid their dissemination by exchange of contaminated plant material; thus, it would reduce costs and an excessive use of fungicides (Mancini et al. 2016).

Traditional techniques for detecting seedborne fungi have been widely used through careful visual examination of seeds after incubation. These techniques are time-consuming, laborious, and not always reliable, except for samples with high levels of pathogen infestation (Atallah et al. 2007; Capote et al. 2012). Diagnostic methods based on quantitative real-time polymerase chain reaction (qPCR) allow a rapid, accurate, and reliable detection of plant pathogens (Sanzani et al. 2014; Schena et al. 2004). Because of its high sensitivity and the use of fluorescence chemistry, TaqMan qPCR also enables the quantification of very low amounts of pathogen DNA, which might match the quantity present in the field at the beginning of infection or during asymptomatic latent infections (Bustin et al. 2009; Schena et al. 2017).

Multiplex qPCR assays have been widely used for pathogen diagnosis in plant material by allowing the simultaneous amplification of multiple DNA targets in a single reaction (Ahmed et al. 2019; Rojas et al. 2017). The technology is based on multiple species-specific primers and probes that are labeled with distinct fluorophores and combined in a single amplification reaction. Amplification products of each pathogen produce a fluorescent signal distinct from each other so that multiple target DNAs can be simultaneously detected by differences in the emission wavelength (Schena et al. 2004). The ability to reduce the number of reactions required to test a sample for multiple targets saves time and money, and it makes multiplex qPCR useful especially for large samples (Sint et al. 2012).
Infected soybean seeds are potential carriers of pathogens for longdistance dissemination. Although a soybean sanitation standard has not yet been established in Brazil, studies about pathogen quantification in seeds are essential to inform producers about the current infection levels of seed lots. For seedborne pathogens, the risk of a disease outbreak usually depends on the amount of inoculum in the seed (Munkvold 2009; Sousa et al. 2015). Few molecular methods are currently available for the direct detection of pathogens in plant tissues. Hence, a molecular assay to detect pathogen DNA in seed sanitation tests is highly desirable, and that could be effectively achieved by qPCR (Glynn and Edwards 2010; Sousa et al. 2015). To improve the diagnostic assays available, this study aimed to (i) develop a multiplex qPCR assay for simultaneous detection and quantification of C. truncatum, C. cassiicola, and S. sclerotiorum in soybean seeds using a seed-soaking method, and (ii) validate the field application of qPCR assays with naturally infected seed samples collected in commercial soybean fields.

\section{Materials and Methods}

Primers and probes. Specific primers and probes were designed for detection of $C$. truncatum based on sequences of the glyceraldehyde 3-phosphate dehydrogenase (GAPDH) gene, previously generated and deposited in NCBI/GenBank (KT696298 to KT696308). For $C$. cassiicola, primer and probe design was based on sequences of elongation factor $1 \alpha$ (TEF1) gene retrieved from GenBank (AB539299 to AB539301, KC748011 to KC748015). Nucleotide sequences were aligned with Clustal Omega (Sievers et al. 2011) for each pathogen separately and evaluated for polymorphism at the intraspecific level for the design of species-specific primers and probes. For this purpose, Primer3 Plus software (http://www.bioinformatics. nl/cgi-bin/primer3plus/primer3plus.cgi/) was used. In addition, the probe design for $C$. truncatum was refined by aligning sequences against six Colletotrichum species associated with anthracnose disease on soybeans: C. coccodes, $C$. chlorophyti, C. incanum, $C$. destructivum, $C$. plurivorum, and $C$. sojae. Species-specific probes were developed based on highly polymorphic regions among Colletotrichum species (and nonvariable regions within C. truncatum isolates) using the following parameters as a guide: (i) melting temperature 8 to $10^{\circ} \mathrm{C}$ higher than the amplification primers; (ii) 18 to 30 nucleotides in length; (iii) GC content of 30 to $80 \%$; (iv) no consecutive repetitions of the same nucleotide, especially guanines; (v) without $\mathrm{G}$ at the $5^{\prime}$ end (quencher effect). The probes' complementarity with and among the primers was also verified.

The developed primers and probes for $C$. truncatum and $C$. cassiicola were used in combination with others to detect four soybean pathogens, listed in Table 1. For detection of S. sclerotiorum, published primers and probes were used, whose effectiveness had previously been tested (Chen et al. 2010; Ramiro et al. 2019). A set of soybean-specific primers and a probe (Soares et al. 2014) was tested as an internal control to identify healthy seed samples that amplify only for the host and thus could be considered pathogen-free. Then, primers Lectin-F and Lectin$\mathrm{R}$, and probe Lectin-TMP (Table 1), were included in the qPCR assay for detection of the soybean lectin gene.

Table 1. Primers and TaqMan probes used for qPCR detection of pathogenic fungi in soybean seeds

\begin{tabular}{|c|c|c|c|}
\hline Primers and probes & Sequence $\left(5^{\prime}-3^{\prime}\right)$ & Target & Reference \\
\hline ColT-F6 & TTGAGACCAAGTAC GCTGTATGTATCAC & Colletotrichum truncatum & This study \\
\hline ColT-R5 & TTCTGCCTCACATCGAACTCTC & & \\
\hline ColT-P & HEX-CAGCCTTCG/ZEN/ACTCTCGTTGGAAAA-IABkFQ & & \\
\hline Cory-F1 & AACTCAACACCATGACGCACAT & Corynespora cassiicola & This study \\
\hline Cory-R6 & CAGGCAGGCAGGACAAGAAAATTTG & & \\
\hline Cory-P & 6-FAM-CCAATTTTG/ZEN/CATCGCCAGCC-IABkFQ & & \\
\hline TY-F & ATATAACGCTACTCTCTCTGTTC & Sclerotinia sclerotiorum & Chen et al. (2010) \\
\hline TY-R & AGCCAACTTTCGGAGATTTG & & \\
\hline TY-P & Cy5-CGAGAACTC/ZEN/TGACGAGACCTTCTGTA-IABkFQ & & \\
\hline Lectin-F & TCCACCCCCATCCACATTT & Glycine $\max$ & Soares et al. (2014) \\
\hline Lectin-R & GGCATAGAAGGTGAAGTTGAAGGA & & \\
\hline Lectin-TMP & TAMRA-AACCGGTAGCGTTGCCAGCTTCG-IAbRQSp & & \\
\hline
\end{tabular}


Specificity and sensitivity of primers. The specificity of the designed assay was first evaluated by conventional PCR, using the following amplification conditions. Reactions were carried out in $25 \mu \mathrm{l}$, with $20 \mathrm{ng}$ of DNA, $10 \mu \mathrm{M}$ of each primer (Table 1), $12.5 \mu \mathrm{l}$ of GoTaq Master Mix (Promega) and $8.5 \mu \mathrm{l}$ of nucleasefree water. The amplification was programmed for $5 \mathrm{~min}$ at $95^{\circ} \mathrm{C}$, followed by 40 cycles of $95^{\circ} \mathrm{C}$ for $30 \mathrm{~s}, 60^{\circ} \mathrm{C}$ for $30 \mathrm{~s}$, and $72^{\circ} \mathrm{C}$ for $30 \mathrm{~s}$, with a final extension of $72^{\circ} \mathrm{C}$ for $5 \mathrm{~min}$. DNA of 20 fungal samples isolated from soybean seeds such as $C$. truncatum, Phomopsis spp., C. cassiicola, S. sclerotiorum, Fusarium sp., Cercospora kikuchii, and Alternaria sp. (Ramiro et al. 2019) were tested for specificity of each primer pair to its target. Amplified fragments were electrophoretically run on $1.5 \%$ agarose gel stained with SYBR Safe (Invitrogen) and visualized under UV light.

qPCR assays. Before being included in the multiplex qPCR system, all primers and probes were tested separately in simplex qPCR reactions to verify DNA amplification of the expected targets. Four concentrations of primers $(80,100,150$, and $200 \mathrm{nM})$ and probes $(100,150,200$, and $300 \mathrm{nM})$ were tested for each target pathogen and also for soybeans, maintaining other amplification conditions. The $S$. sclerotiorum probe (TY-P) was labeled with a distinct fluorophore (Cy5) at the $5^{\prime}$ end to avoid overlap of wavelengths in combination with other probes (Table 1).

To define the best optimized qPCR conditions, concentration gradients of qPCR components were first tested in singleplex and then in multiplex (duplex, triplex, and tetraplex, including all possible combinations). Combinations of primers and probes were selected that generated amplicons with lower threshold cycle $\left(\mathrm{C}_{\mathrm{T}}\right)$ and higher $\Delta \mathrm{Rn}$ values. Assuming that host DNA should be the most abundant in the samples, the concentrations of lectin primers and probes were adjusted to the lowest. Thus, it was possible to amplify soybean DNA without hindering the amplification of any pathogen DNA.

Because the $C_{T}$ values were very similar for amplification of the pooled targets in comparison with target amplifications separately, multiplex qPCR tests were performed using primer and probe triads. For that, DNA dilution of the samples was maintained individually at a concentration of $5 \mathrm{ng} / \mu \mathrm{l}$ at a volume of $3 \mu \mathrm{l}$ per reaction. From these, samples composed of three target DNAs were constructed for testing (two pathogens + soybean or three pathogens combined). The conditions of the qPCR were the same as described above, by adjusting the annealing temperature to $60^{\circ} \mathrm{C}$ in the multiplex reaction.

The tetraplex reaction mixture was composed as follows: $30 \mathrm{ng}$ of DNA, $6 \mu$ l of Path-ID qPCR Master Mix (Thermo Fisher), $200 \mathrm{nM}$ primers ColTF6/ColTR5 and TY-F/TY-R, $100 \mathrm{nM}$ primers CoryF1/ CoryR6, and $80 \mathrm{nM}$ primers Lectin-F/Lectin-R, combined with $300 \mathrm{nM}$ probe ColT-P (VIC-labeled), $150 \mathrm{nM}$ probe TY-P (Cy5), and $100 \mathrm{nM}$ probes Cory-P (6-FAM) and Lectin-TMP (TAMRA). Nuclease-free water was added to a final volume of $12 \mu \mathrm{l}$. The amplification program started at $95^{\circ} \mathrm{C}$ for $10 \mathrm{~min}$, followed by 45 cycles at $95^{\circ} \mathrm{C}$ for $15 \mathrm{~s}$ and $60^{\circ} \mathrm{C}$ for $1 \mathrm{~min}$ in a 7500 Fast Real-Time PCR System (Applied Biosystems). The multiplex qPCR assay was also tested with other pathogenic fungi associated with soybean seeds. Nuclease-free water was used as a negative control (nontemplate control). Data analysis was based on $\mathrm{C}_{\mathrm{T}}$ values, manually adjusted in the exponential phase of the amplification, where the curves were parallel. The $C_{T}$ values of each reaction were accessed using software 7500 version 2.0.6 (Applied Biosystems).

Standard curves for quantification of pathogen DNA by qPCR. DNA samples from each fungal species were used for constructing standard curves, from a serial dilution of seven times the initial DNA concentration ( $300 \mathrm{ng} / \mu \mathrm{l}$ to $300 \mathrm{fg} / \mu \mathrm{l}$ or $3 \times 10^{2}$ to $3 \times 10^{-4}$ $\mathrm{ng} / \mu \mathrm{l})$. For each dilution, three technical replicates were conducted, using the same qPCR conditions described for each fungus. Standard curves were used for an accurate DNA quantification of target pathogens in soybean seed samples, because it is directly proportional to their biomass (Schena et al. 2004). The lowest DNA concentration detected in at least $95 \%$ of the qPCR runs was set as the sensitivity level or the limit of detection (LOD) of the assay, estimated for each pathogen. Standard curves must exhibit linearity, and efficiency of the amplification reactions is expected to be within the acceptable range of 90 to $110 \%$ (Kavanagh et al. 2011). Due to the synthesis of a new probe for $S$. sclerotiorum with a fluorophore distinct from that previously used (Ramiro et al. 2019), adjustments were made to primer and probe concentrations in the qPCR reactions, in order to increase the amplification efficiency. With these adjustments, the standard curve for amplification of $S$. sclerotiorum was recomposed.

Sensitivity evaluation of fungi detection method in soybean seeds by qPCR. Soybean seeds of Pioneer 97R01 cultivar obtained in the 2012 to 2013 season were submitted to sanitation tests according to the Seed Analysis Rules (Brazil 2009). Tested soybean seeds were free from the pathogens under study and therefore considered healthy. Before being inoculated, seeds were surface disinfested with $1 \%$ sodium hypochlorite for $30 \mathrm{~s}$, rinsed with distilled water, and then dried on filter paper for $48 \mathrm{~h}$ at room temperature.

To evaluate the sensitivity level or the LOD of the proposed method, soybean seeds were artificially inoculated with the target pathogens, separately. Inoculations were carried out by deposition of mycelium discs of one isolate of each fungus on Petri dishes with potato dextrose agar (PDA) culture medium, followed incubation at $25^{\circ} \mathrm{C}$ under a photoperiod of $12 \mathrm{~h}$. When the fungal colonies had reached the entire diameter of the plates, soybean seeds were deposited in a single layer on top of each colony and kept for $24 \mathrm{~h}$ in the same incubation conditions. Thereafter, seeds were removed from the plates and placed to dry on filter paper for 3 days at room temperature. Afterward, they were transferred to paper bags and stored in a cold room (Machado et al. 2001; Ramiro et al. 2019).

Dilutions to obtain different inoculum concentrations were performed by mixing artificially infested seeds with noninfected seeds to generate samples with varying percentages of contamination (or infestation levels). The following proportions were tested (infested/ noninfested seeds): 1:399, 1:799, 1:1,599, which correspond to incidence levels of $0.25,0.125$, and $0.0625 \%$ respectively. These dilutions were performed in triplicate to test the sensitivity of the qPCR method.

The seed-soaking method (Grabicoski et al. 2015), successfully applied in qPCR detection of pathogenic fungi (Ramiro et al. 2019), was used for a simultaneous detection of the four pathogens and the host by qPCR. In this method, batches of 400, 800, and 1,600 soybean seeds, inoculated with each pathogen separately in the proportions described above, were incubated in sealed flasks with, respectively, 400,800, and 1,600 ml of sterilized Milli-Q ultrapure water at $20 \pm 2{ }^{\circ} \mathrm{C}$ for $4 \mathrm{~h}$. From the seed-soaking solutions, 50$\mathrm{ml}$ aliquots were collected and centrifuged at 4,000 rpm for $20 \mathrm{~min}$, and $1-\mathrm{ml}$ supernatant aliquots were stored at $-20^{\circ} \mathrm{C}$ for amplification purposes. Aliquots from seed-soaking solutions with different infestation levels were used directly as templates for qPCR under the conditions stated above. Quantification of the amplified product for each target pathogen was based on the correspondent standard curves. As positive controls, DNA of each target fungus and aliquots of $100 \%$ inoculated seeds were used; as negative controls, we utilized aliquots of embedded healthy seeds and ultrapure sterile water.

Monitoring of fungi associated with naturally infected soybean seeds. Aiming to survey the occurrence of the three target pathogens in the main soybean production areas in Brazil, 81 samples of soybean seed lots from the 2013 to 2014 and the 2014 to 2015 seasons, coming from Goiás, Minas Gerais, Paraná, Rio Grande do Sul, and Mato Grosso states, were evaluated. Seed samples were not identified by the cultivar due to a confidentiality agreement established with the suppliers. From each sample, aliquots of the 400 soaking seeds were processed and stored as previously described. Samples were tested for the presence of $C$. truncatum, $C$. cassiicola, and S. sclerotiorum in multiplex qPCR assays. For each sample, three technical replicates were done to obtain mean $\mathrm{C}_{\mathrm{T}}$ values. A sample was considered positive if at least two replicates out of three yielded a $C_{T}$ value.

\section{Results}

Specificity and sensitivity of PCR detection. The designed primer pairs ColT-F6/ColT-R5 and Cory-F1/Cory-R6 were quite specific to detect, respectively, C. truncatum and C. cassiicola by conventional PCR. Only isolates of each target species were 
amplified and not from any other fungus tested. The detection set for the host, composed by Lectin-F and Lectin-R primers and LectinTMP probe, was also highly specific and could be included in the multiplex assays.

Likewise, high specificity levels were noted in the simplex qPCR assays. The detection set ColT-F6/ColT-R5/ColT-P only showed amplification of $C$. truncatum isolates. By using the Cory-F1/ Cory-R6/Cory-P set, exclusive amplification of $C$. cassiicola isolates was also achieved, evidencing its potential use in the detection and quantification of these target pathogens in soybean seeds (Table 2).

qPCR assays. Preliminary tests were run to confirm the possibility to multiplex the four primers and probes without compromising qPCR sensitivity and efficiency. Duplex qPCR was successful in the detection of paired targets. It was also possible to simultaneously amplify DNA of the three fungi (C. cassiicola, $C$. truncatum, and $S$. sclerotiorum) separately or combined, one by one, with soybean DNA, with small variation in $\mathrm{C}_{\mathrm{T}}$ values as compared with amplifications in singleplex (Supplementary Fig. S1). Simultaneous amplification of the four tested targets was first observed from a DNA mixture of these targets, enabling the combination of primers and probes for the simultaneous detection of three plant pathogens and the host (Fig. 1). Amplification of soybean DNA in the multiplex qPCR assay allowed identifying contamination-free seed samples by acting as a positive control of the amplification reaction.

Standard curves for the quantification of pathogen DNA by $\mathbf{q P C R}$. The construction of standard curves is the most reliable and robust approach to estimate the amplification efficiency and the linearity for each target in a multiplex qPCR assay. Based on the serial dilutions of $C$. truncatum DNA, qPCR amplification occurred up to the minimum tested DNA concentration of $300 \mathrm{fg}$ $\left(3 \times 10^{-4} \mathrm{ng}\right)$, with a correspondent $\mathrm{C}_{\mathrm{T}}$ value of $40.37 \pm 0.21$ (Table 2). For C cassiicola, serial DNA dilutions were also amplified until the lowest DNA concentration of $300 \mathrm{fg}\left(\mathrm{C}_{\mathrm{T}}=38.27 \pm 0.54\right)$. Amplification of the serial dilutions of $S$. sclerotiorum DNA resulted in the detection of up to $3 \mathrm{pg}$ of DNA $\left(\mathrm{C}_{\mathrm{T}}=42.00 \pm 0.91\right)$. All these values are presented in Table 2. Standard curves showed linearity for all the fungal species (Supplementary Fig. S2), with distinct efficiency in the amplification reaction: $96.5 \%$ for $C$. truncatum, $99.64 \%$ for C. cassiicola, and $109.87 \%$ for S. sclerotiorum, all within the acceptable range.

For all target pathogens, the lowest DNA amount detected in at least $95 \%$ of the qPCR runs was set as the analytical sensitivity or the LOD of the method. $\mathrm{C}_{\mathrm{T}}$ values corresponding to the lowest DNA concentrations detected were used as a reference for maximum $\mathrm{C}_{\mathrm{T}}$ values accepted for positive detection with confidence (Table 2). Those reference values were estimated for each target separately. So, the highest $\mathrm{C}_{\mathrm{T}}$ values accepted as a positive detection of fungal pathogens in soybean seeds (or LOD) were 40.37 for C. truncatum, 38.27 for $C$. cassiicola, and 42.00 for $S$. sclerotiorum.

Sensitivity evaluation of fungi detection method in soybean seeds by qPCR. The method using soaked seeds in ultrapure water

Table 2. Detection limit based on DNA serial dilutions of Colletotrichum truncatum, Corynespora cassiicola, and Sclerotinia sclerotiorum by qPCR

\begin{tabular}{|c|c|c|c|}
\hline \multirow[b]{2}{*}{ DNA amount } & \multicolumn{3}{|c|}{$\mathrm{C}_{\mathrm{T}}$ values $^{\mathrm{a}}$} \\
\hline & C. truncatum & C. cassiicola & S. sclerotiorum \\
\hline $3 \times 10^{2} \mathrm{ng}(300 \mathrm{ng})$ & $20.86 \pm 0.20$ & $18.63 \pm 0.30$ & $27.27 \pm 1.67$ \\
\hline $3 \times 10^{1} \mathrm{ng}(30 \mathrm{ng})$ & $24.10 \pm 0.12$ & $21.48 \pm 0.09$ & $28.49 \pm 0.31$ \\
\hline $3 \times 10^{0} \mathrm{ng}(3 \mathrm{ng})$ & $27.53 \pm 0.03$ & $27.74 \pm 0.69$ & $31.39 \pm 0.50$ \\
\hline $3 \times 10^{-1} \mathrm{ng}(300 \mathrm{pg})$ & $30.81 \pm 0.02$ & $27.24 \pm 0.17$ & $34.82 \pm 0.09$ \\
\hline $3 \times 10^{-2} \mathrm{ng}(30 \mathrm{pg})$ & $34.67 \pm 0.23$ & $30.90 \pm 0.18$ & $38.86 \pm 0.24$ \\
\hline $3 \times 10^{-3} \mathrm{ng}(3 \mathrm{pg})$ & $37.69 \pm 0.31$ & $35.58 \pm 1.20$ & $42.00 \pm 0.91^{b}$ \\
\hline $3 \times 10^{-4} \mathrm{ng}(300 \mathrm{fg})$ & $40.37 \pm 0.21^{b}$ & $38.27 \pm 0.54^{\mathrm{b}}$ & N.A. ${ }^{c}$ \\
\hline
\end{tabular}

${ }^{a}$ Mean threshold cycle $\left(\mathrm{C}_{\mathrm{T}}\right)$ values of three technical replicates \pm standard deviation.

${ }^{\mathrm{b}}$ Limit of detection (LOD): the lowest DNA concentration detected in at least $95 \%$ of the qPCR runs.

${ }^{c}$ N.A. $=$ no amplification up to 45 cycles . allowed the detection of all target pathogens in artificially inoculated seeds by qPCR, up to the minimum incidence level tested of $0.0625 \%$, which corresponds to one inoculated seed for a total of 1,600 healthy seeds (Table 3 ). The proposed method was highly sensitive in the detection of pathogens at very low incidence levels, by accessing fungal DNA released from the soaked soybean seeds to the solution by qPCR. The reliability of the quadruplex qPCR assay was further validated by detecting the targets on 81 samples of naturally infected soybean seeds.

Monitoring of fungi associated with naturally infected soybean seeds. There was a great variation in the incidence levels of the four target pathogens in soybean seed samples among the producer states across the country. Overall, in the 81 samples tested by qPCR, $C$. truncatum was the most frequent pathogen detected (Table 4), with an incidence of $39.5 \%$, followed by S. sclerotiorum $(33.3 \%)$ and C. cassiicola $(17.3 \%)$. In all but one sample, host DNA was detected (mean $\mathrm{C}_{\mathrm{T}}$ 35.27); thus, the inclusion of primers and probes for host amplification in the multiplex qPCR successfully performed as a positive internal control of the sample's DNA quality.

When regions were evaluated separately, a distinct predominance of pathogens in each area was observed (Table 4, Fig. 2). In the samples from Goiás, the pathogen with the highest incidence was $C$. truncatum, detected in $53.3 \%$ of the samples, followed by S. sclerotiorum $(26.7 \%)$ and $C$. cassiicola $(13.3 \%)$. Among the samples from Minas Gerais, the lowest incidence was also reached by $C$. cassiicola (12.5\%), and similar proportions of infected seeds with $C$. truncatum $(50 \%)$ and S. sclerotiorum $(56.3 \%)$ were observed. The highest incidence was of S. sclerotiorum (35\%) in the samples from Paraná, followed by C. truncatum (33\%), and only $10 \%$ of the samples were infected with $C$. cassiicola. In Mato Grosso, the highest incidence of $C$. cassiicola was detected among the seed samples (41.7\%), together with $16.7 \%$ incidence of S. sclerotiorum and only $8.3 \%$ of C. truncatum. In one of the three samples tested from Rio Grande do Sul, we were able to identify the three target pathogens; in the remaining two samples, no pathogens were detected. $C_{T}$ values related to the detection of each pathogen in all seed samples tested are available in Supplementary Table S1.

From the total of 81 soybean seed samples evaluated, 32 (39.5\%) were considered healthy or pathogen-free, in which none of the pathogens were detected, only the host DNA (Supplementary Table S1). In some of these samples, some amplification of pathogen DNA was observed, but with $\mathrm{C}_{\mathrm{T}}$ values higher than the LOD (values in bold, Supplementary Table S1); thus, they were not considered contaminated. Twelve of these healthy samples came from Goiás (representing $40 \%$ of total samples from this state), six from Minas Gerais (37.5\%), and 11 from Paraná (55\%); other samples were positive for one or more pathogens, which revealed medium to low sanitation levels in soybean seeds from all the regions. These results differed from detection by traditional methods of seed analysis, for which

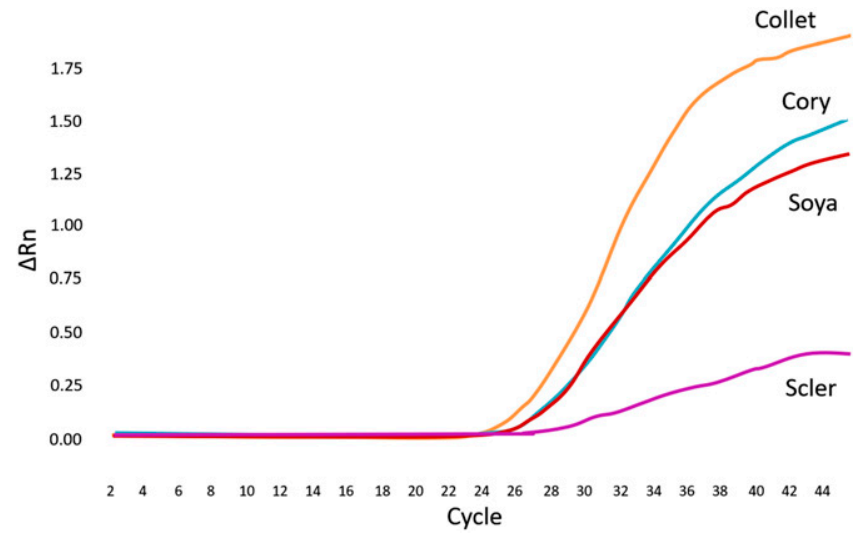

Fig. 1. Concomitant amplification of four DNA targets by multiplex qPCR: Colletotrichum truncatum (Collet), Corynespora cassiicola (Cory), Sclerotinia sclerotiorum (Scler), and soybean (Soya). 
typical structures of each pathogenic fungus were observed in a few of these samples only (Ramiro et al. 2019), evidencing a more sensitive detection by the $\mathrm{qPCR}$ detection method proposed.

Based on the correlation between $\mathrm{C}_{\mathrm{T}}$ values associated with amplification of artificially inoculated seeds for each pathogen (Table 3 ) and those obtained by the amplification of target pathogens in the soybean seed samples, it was possible to roughly estimate the incidence levels of seeds infected by these pathogens (Table 5). The detection of $C$. truncatum indicated that 18 of the 35 positive samples had incidence levels between 0.125 and $0.25 \%$, or one infected seed in batches of 400 to 800 seeds. For C. cassiicola and S. sclerotiorum, most of the infected samples had lower incidence levels, between 0.0625 and $0.125 \%$, or one infected among 800 to 1,600 seeds. Together, the detection results evidenced the high sensitivity of the multiplex qPCR assay, by allowing the detection of three target pathogens in seed samples at levels as low as $0.0625 \%$, or one contaminated seed in a batch of 1,600 seeds. Using traditional seed health tests, most of these seed samples would be considered healthy based on the low levels of contamination showed here.

\section{Discussion}

Seeds represent a particularly efficient vehicle to disperse seedborne pathogens, because they constitute a safe refuge for survival and efficient transport of pathogens over long distances. The use of high sanitary quality seed decreases the primary inoculum in a field and is among the most effective strategies to reduce the spread of seedborne pathogens (Choudhury et al. 2017; Guimarães et al. 2017). According to the Brazilian legislation for seed health, the analysis of a standard sample of 400 seeds per batch is recommended (Brazil 2009). However, our results reinforce the possibility of failure in detecting the target pathogens safely and reliably when only 400 seeds are tested, which could lead to a false negative result (Henneberg et al. 2012; Ramiro et al. 2019). Consequently, false negative results may contribute to transport contaminated seeds to the field, promoting inoculum dissemination.

This paper reports the development, validation, and sensitivity of a multiplex TaqMan qPCR assay for simultaneous detection and quantification of C. truncatum, C. cassiicola, and S. sclerotiorum in soybean seeds. The method could be applied to DNA accessed directly

Table 3. Quantification of Colletotrichum truncatum, Corynespora cassiicola, and Sclerotinia sclerotiorum in inoculated soybean soaking seeds by qPCR with distinct infestation levels

\begin{tabular}{lcccc}
\hline \multirow{2}{*}{$\begin{array}{l}\text { Infestation } \\
\text { levels }\end{array}$} & \multicolumn{4}{c}{$\mathbf{C}_{\mathbf{T}}$ values $^{\mathbf{a}}$} \\
\cline { 2 - 5 } & C. truncatum & C. cassiicola & S. sclerotiorum $^{\text {Soybean }}$ \\
\hline $100 \%$ & $29.58 \pm 0.16$ & $31.39 \pm 0.25$ & $33.99 \pm 0.09$ & $29.24 \pm 0.36$ \\
$0.25 \%$ & $33.86 \pm 0.22$ & $32.60 \pm 1.04$ & $36.38 \pm 0.41$ & $30.18 \pm 0.45$ \\
$0.125 \%$ & $36.99 \pm 0.61$ & $35.08 \pm 0.15$ & $38.75 \pm 0.47$ & $31.53 \pm 0.33$ \\
$0.0625 \%$ & $40.12 \pm 0.92$ & $38.26 \pm 0.53$ & $41.12 \pm 0.81$ & $32.90 \pm 0.55$ \\
$0 \%{ }^{b}$ & N.A. $^{\text {c }}$ & N.A. & N.A. & $30.82 \pm 0.60$ \\
\hline
\end{tabular}

a Mean threshold cycle $\left(\mathrm{C}_{\mathrm{T}}\right)$ values of three technical replicates \pm standard deviation.

b Uninoculated control seeds.

${ }^{\mathrm{c}}$ N.A. $=$ no amplification up to 45 cycles . from seed-soaking solution, and it is not influenced by a nonspecific background from coextracted plant DNA. The detection sets of probe and primers were evaluated by amplifying the DNA from pureculture isolates of the four target pathogens along with the host. Specificity of the detection assay was assessed by DNA amplification of only the target species, and not of other fungi commonly associated with soybean seeds, without any amplification signal. This high specificity provided by the internal TaqMan probes is advantageous in overcoming the risks of false positives and negatives.

High sensitivity was achieved by the multiplex assay, by consistently detecting as little as $3 \mathrm{pg}$ of $S$. sclerotiorum DNA or even less, such as $300 \mathrm{fg}$ of $C$. truncatum and $C$. cassiicola DNA released from soybean seeds in the soaking solution. The inclusion of an internal plant control acted as a control of failed amplifications. TaqMan qPCR offers a much lower chance of getting a false positive result in a cross-reaction mixture than conventional PCR (Tomlinson et al. 2005). A minimum of $200 \mathrm{pg}$ of $C$. cassiicola DNA and 10 pg of $S$. sclerotiorum DNA was previously required to detect them in soybean seeds by conventional PCR (Grabicoski et al. 2015; Sousa et al. 2016), and $4 \mathrm{pg}$ of $C$. cassiicola DNA by SYBR qPCR (Guimarães et al. 2017). Our multiplex qPCR assay using TaqMan probes was much more sensitive and accurate, in which lower DNA amounts of the target pathogens were detected. For diagnosis of $C$. truncatum, multiplex real-time PCR assays had been proposed to discern four Colletotrichum species infecting soybean (C. chlorophyti, Glomerella glycines, $C$. incanum, and $C$. truncatum), by using two duplex sets based on melting point temperatures. Successful detection was achieved with as little as $0.1 \mathrm{pg}$ of $C$. truncatum DNA. However, the assay is not suitable for field diagnostics, because it detected and distinguished only individually purified Colletotrichum isolates (Yang et al. 2015).

qPCR has been widely applied to detect and quantify plant pathogens within different host tissues. Its high level of sensitivity enables the quantification of very low fungal propagule concentrations, which might correspond to the amount present at the beginning of infection or during latent, nonsymptomatic infections (Sanzani et al. 2014). Using artificially infested soybean seeds with each pathogen, in distinct inoculum potentials, we were able to correlate $C_{T}$ values with DNA amount of the target pathogens. Thus, as the inoculum potential and pathogen incidence increased, the amount of fungal DNA detected by qPCR increased as well. The developed qPCR assays enabled the detection and quantification of the four pathogens in seed samples with infection levels of $0.0625 \%$, meaning only one infected seed in batches of 1,600 seeds. For both C. cassiicola and S. sclerotiorum, the minimum incidence levels previously detected in soybean seeds by conventional PCR were $0.25 \%$ (Grabicoski et al. 2015; Sousa et al. 2016). The assay was validated with soybean seed samples collected in commercial fields between 2013 and 2015, and its applicability has been demonstrated to detect the four target pathogens in seeds.

Using the proposed qPCR assays, a reliable DNA quantification of target pathogens was reached, once $\mathrm{C}_{\mathrm{T}}$ values from most seed samples were below the LOD determined by DNA standard curves for each pathogen. Most seed samples positively detected for $C$. truncatum showed low incidence levels $(0.125$ to $0.25 \%)$, and even lower for C. cassiicola and S. sclerotiorum (0625 to $0.125 \%$ ). Therefore,

Table 4. Multiplex qPCR detection of Colletotrichum truncatum, Corynespora cassiicola, and Sclerotinia sclerotiorum in commercial soybean seed samples from five Brazilian states ${ }^{\mathrm{a}}$

\begin{tabular}{|c|c|c|c|c|c|c|c|}
\hline \multirow[b]{2}{*}{ Origin of soybean seed samples } & \multirow[b]{2}{*}{$N$} & \multicolumn{2}{|c|}{ C. truncatum } & \multicolumn{2}{|c|}{ C. cassiicola } & \multicolumn{2}{|c|}{ S. sclerotiorum } \\
\hline & & Mean $C_{T}$ & qPCR + & Mean $\mathbf{C}_{\mathbf{T}}$ & qPCR + & Mean $\mathbf{C}_{\mathbf{T}}$ & qPCR + \\
\hline Goiás & 30 & 36.44 & $(16 / 30)$ & 35.73 & $(4 / 30)$ & 36.94 & $(8 / 30)$ \\
\hline Minas Gerais & 16 & 36.91 & $(8 / 16)$ & 36.68 & $(2 / 16)$ & 38.21 & $(9 / 16)$ \\
\hline Paraná & 20 & 38.06 & $(6 / 20)$ & 38.30 & $(2 / 20)$ & 39.90 & $(7 / 20)$ \\
\hline Rio Grande do Sul & 3 & 36.41 & $(1 / 3)$ & 34.25 & $(1 / 3)$ & 38.72 & $(1 / 3)$ \\
\hline Mato Grosso & 12 & 40.66 & $(1 / 12)$ & 38.45 & $(5 / 12)$ & 39.90 & $(2 / 12)$ \\
\hline Total & 81 & & 32 & & 14 & & 27 \\
\hline
\end{tabular}

a Samples with threshold cycle $\left(\mathrm{C}_{\mathrm{T}}\right)$ values below the limit of detection (estimated for each fungus) were considered positive. 
the infestation levels detected for all of the tested pathogens might be considered low, unlike the previous Phomopsis spp. diagnosis, for which most samples had incidence levels greater than or equal to $0.25 \%$ (Ramiro et al. 2019). However, 10 out of 81 samples $(12.3 \%)$ showed some amplification levels, but with $\mathrm{C}_{\mathrm{T}}$ values above the LOD, suggesting a possible presence of the target pathogens, although at very low inoculum density. For those samples, estimation of propagule density is limited, based on data interpretation.

In some cases, a simple fungal detection without the need for quantification would be sufficient to monitor seed health. Some pathogens, such as $S$. sclerotiorum, categorized as a quarantine pest due to its potential for destruction and difficulty in its control, have received a zero tolerance proposition regarding their presence in soybean seed samples submitted to sanitary analysis by certification programs of quality in Brazil (Botelho et al. 2015; Machado and Pozza 2005). Our data pointed to the alarming presence of S. sclerotiorum DNA in one-third of the seed samples tested, even though in low concentrations. Once established, the white mold caused by the pathogen is difficult to manage, stressing the importance of seed health. Out of 21 samples positive for $C$. cassiicola in the qPCR assays, only three would have their presence detected by traditional detection tests, which means that most seed samples would be considered healthy, leading to an increased risk of pathogen introduction into new areas. Therefore, the amount of 400 seeds currently recommended for sanitation tests in the country (Brazil 2009) is not appropriate for a reliable detection of the target pathogens, so that larger seed samples or more sensitive detection methods are required.

A shortcoming in our study is the ability to detect fungal propagules only on the surface and not inside soybean seeds. Many attempts to detect fungal DNA in macerated seeds were done; in all of them we could only detect pathogens in inoculated seeds at $100 \%$ incidence level. There was no amplification of any target pathogen at other incidence levels tested $(0.25,0.125$, and $0.0625 \%)$. A failure in fungal DNA amplification could be attributed to the presence of commonly found PCR inhibitors in macerated seed extracts (Giovanardi et al. 2018; Ma and Michailides 2007; Sousa et al. 2015; Walcott et al. 2004). Inhibitors may interfere with DNA amplification, especially at lower levels of pathogen inoculum, for which the proportion of fungal DNA is much lower than host DNA in the seed extract. Hence, the alternative to access fungal DNA by the seed-soaking method (Grabicoski et al. 2015; Ramiro et al. 2019) was successfully extended to the detection of the four pathogens and the soybean DNA.

The inclusion of a detection set to amplify soybean DNA in the multiplex qPCR system allowed the identification of pathogen-free

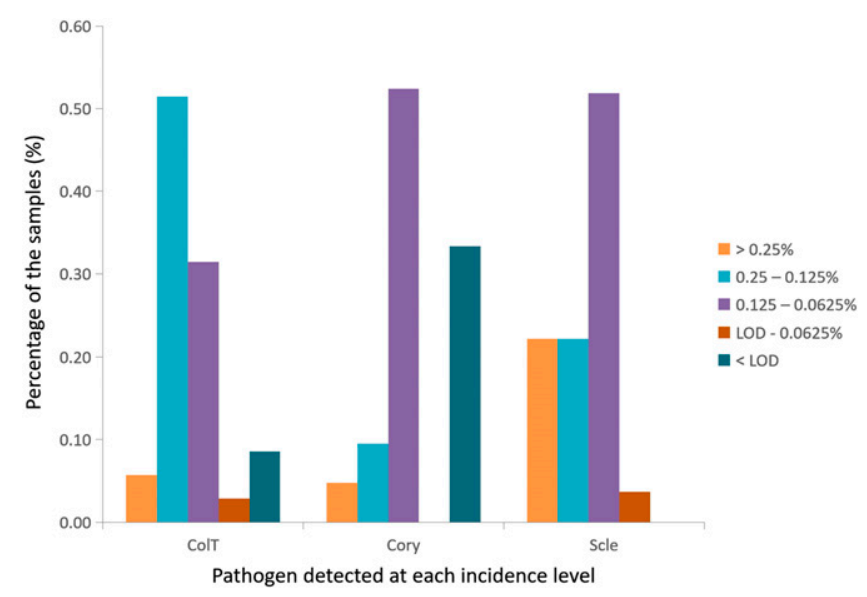

Fig. 2. Total incidence levels of Colletotrichum truncatum (ColT), Sclerotinia sclerotiorum (Scle), and Corynespora cassiicola (Cory) in 81 soybean seed samples from Brazilian states of Goiás, Minas Gerais, Paraná, Rio Grande do Sul, and Mato Grosso, detected by multiplex qPCR. Samples that did not amplify for any target pathogen or showing $\mathrm{C}_{\mathrm{T}}$ values below the limit of detection (LOD), although amplified for the host, were considered healthy. seed samples, acting as a positive control of the amplification reaction. Out of the 81 seed samples tested, only one had no amplification of any pathogen, nor of soybean, so it is not possible to state whether it was a healthy sample or not. High concentrations of host DNA may reduce the detection sensitivity of pathogen DNA in multiplex qPCR when there are host-targeted primers in the soaking solution of soybean seeds, as expected. Therefore, the concentration of soybeanspecific primer pairs was reduced to the lowest level capable of amplifying the target DNA.

The lack of discrimination between living and dead propagules is among the limitations of qPCR to diagnose plant pathogens. Because qPCR assays detect DNA rather than living cells, there is a risk that DNA departed from dead and nonviable cells may lead to positive amplifications (Sanzani et al. 2014). Association of qPCR with traditional methods would be a viable alternative, by employing qPCR to screen a large number of samples and submitting only qPCR-positive samples to culture techniques, to ensure the viability of the target pathogens detected. Another possibility is the use of dyes that bind DNA into nonviable cells and inhibit their amplification by qPCR, such as propidium monoazide (PMA) (Fittipaldi et al. 2012). By using PMA, only viable, mature spores of Plasmodiophora brassicae associated with clubroot disease of Brassica crops were amplified, and the proportion of nonviable or immature spores was directly assessed by PCR (Al-Daoud et al. 2017), as well as viable conidia of Monilinia fructicola in flower and stone fruit (Vilanova et al. 2017).

A further step in this research would be analyze the concentration of DNA from these pathogens in whole soybean seeds and dissected fractions (tegument and embryo), in all inoculum potentials, aiming to better understand their host infection and colonization process. For instance, lower concentrations of $C$. lindemuthianum DNA infecting beans was detected in the embryo than in the tegument. At the highest inoculum potentials, the pathogen could colonize seed inner vital tissues and then compromise the vigor and quality (Gadaga et al. 2018). By monitoring by qPCR, Fusarium fujikuroi was found to be more diffused in the rice green tissues and in the roots to a lesser extent at 1 week postgermination, whereas 2 weeks later the fungus was uniformly spread in the plant tissues, and the difference between the roots and green tissues became negligible (Carneiro et al. 2017). The use of fluorescent in situ hybridization with specific probes has arisen as an alternative to follow fungal colonization, and it was successfully used to estimate the abundance of Sclerotium rolfsii in soil samples, once the DNA amount of $S$. rolfsii had a great correlation with the hybridization signal detected in soil for $S$. rolfsii (Milner et al. 2019).

Table 5. Quantification of Colletotrichum truncatum, Corynespora cassiicola, and Sclerotinia sclerotiorum in soybean seed samples by qPCR

\begin{tabular}{|c|c|c|c|}
\hline Pathogen & Incidence levels $^{\mathbf{a}}$ & $\mathrm{C}_{\mathrm{T}}$ values $^{\mathrm{b}}$ & Number of samples \\
\hline \multirow[t]{5}{*}{ C. truncatum } & $<\operatorname{LOD}^{\mathrm{c}}$ & $>40.37$ & 3 \\
\hline & LOD to $0.0625 \%$ & $40.37-40.12$ & 1 \\
\hline & $0.0625-0.125 \%$ & $40.11-36.99$ & 11 \\
\hline & $0.125-0.25 \%$ & $36.98-33.86$ & 18 \\
\hline & $>0.25 \%$ & $<33.86$ & 2 \\
\hline \multirow[t]{5}{*}{ C. cassiicola } & $<$ LOD & $>38.27$ & 7 \\
\hline & LOD to $0.0625 \%$ & $38.27-38.26$ & 0 \\
\hline & $0.0625-0.125 \%$ & $38.25-35.08$ & 11 \\
\hline & $0.125-0.25 \%$ & $35.07-32.60$ & 2 \\
\hline & $>0.25 \%$ & $<32.60$ & 1 \\
\hline \multirow{5}{*}{ S. sclerotiorum } & $<$ LOD & $>42.00$ & 0 \\
\hline & LOD to $0.0625 \%$ & $42.00-41.12$ & 1 \\
\hline & $0.0625-0.125 \%$ & $41.11-38.75$ & 14 \\
\hline & $0.125-0.25 \%$ & $38.75-36.38$ & 6 \\
\hline & $>0.25 \%$ & $<36.38$ & 6 \\
\hline
\end{tabular}

a Reference values were estimated by artificially inoculated soybean seeds with each pathogen.

${ }^{b}$ Mean threshold cycle $\left(\mathrm{C}_{\mathrm{T}}\right)$ values of three technical replicates.

${ }^{c}$ Because it was not possible to detect the pathogens in samples with $\mathrm{C}_{\mathrm{T}}$ values above the limit of detection (LOD) with confidence, those samples were considered healthy. 
The proposed multiplex qPCR assay quantified the target pathogens in seed lots and indicated disease risks associated with seedborne inoculum. The assay sensitivity to detect seedborne pathogens at very low incidence levels (up to $0.0625 \%$ of infected seeds) demonstrated its viability by detecting pathogens in samples that traditional methods would not. Due its high sensitivity and accuracy, the implementation of qPCR-based diagnosis in seed certification programs could be strongly recommended to quickly detect the four target pathogens, which could help to assess their infection level within commercial soybean seeds. The multiplex assay described here may also be useful to detect latent infections within seedlings or adult plants, especially for pathogens associated with end-cycle soybean diseases, such as $C$. truncatum. The time taken to perform a blotter test (minimum of 7 days) can be reduced to a few hours when using qPCR so that a large number of samples can be processed within a short period of time. A more routine use of molecular detection tools like qPCR has definitive advantages for seed health tests in terms of speed, specificity, and technical simplicity. It can be used to discard contaminated seed, to test the efficacy of seed treatments, and to plan eradication measures to prevent the spread of pathogens (Sanzani et al. 2014). This approach would further provide clearer insights into the epidemiology of $C$. truncatum, $C$. cassiicola, and $S$. sclerotiorum and open new ways to study their infection process and the effect of management strategies on their spread.

\section{Acknowledgments}

We thank Prof. Luís Eduardo Aranha Camargo for making real-time PCR equipment available. We also thank the seed distribution companies who kindly provided us with soybean seed samples.

\section{Literature Cited}

Ahmed, Y., Hubert, J., Fourrier-Jeandel, C., Dewdney, M. M., Aguayo, J., and Ioos, R. 2019. A set of conventional and multiplex real-time PCR assays for direct detection of Elsinoe fawcettii, E. australis, and Pseudocercospora angolensis in citrus fruits. Plant Dis. 103:345-356.

Al-Daoud, F., Gossen, B. D., Robson, J., and McDonald, M. R. 2017. Propidium monoazide improves quantification of resting spores of Plasmodiophora brassicae with qPCR. Plant Dis. 101:442-447.

Allen, T. W., Bradley, C. A., Sisson, A. J., Byamukama, E., Chilvers, M. I., Coker, C. M., Collins, A. A., Damicone, J. P., Dorrance, A. E., Dufault, N. S., Esker, P. D., Faske, T. R., Giesler, L. J., Grybauskas, A. P., Hershman, D. E., Hollier, C. A., Isakeit, T., Jardine, D. J., Kelly, H. M., Kemerait, R. C., Kleczewski, N. M., Koenning, S. R., Kurle, J. E., Malvick, D. K., Markell, S. G., Mehl, H. L., Mueller, D. S., Mueller, J. D., Mulrooney, R. P., Nelson, B. D., Newman, M. A., Osborne, L., Overstreet, C., Padgett, G. B., Phipps, P. M., Price, P. P., Sikora, E. J., Smith, D. L., Spurlock, T. N., Tande, C. A., Tenuta, A. U., Wise, K. A., and Wrather, J. A. 2017. Soybean yield loss estimates due to diseases in the United States and Ontario, Canada from 2010 to 2014. Plant Health Prog. 18:19-27.

Almeida, A. M. R., Ferreira, L. P., Yorinori, J. T., Silva, J. F. V., and Henning, A. A. A. 2005. Doenças da soja. Pages 569-588 in: Manual de Fitopatologia: Doenças das Plantas Cultivadas. H. Kimati, L. Amorim, A. Bergamin Filho, L. E. A. Camargo, and J. A. M. Rezende, eds. Agronômica Ceres, São Paulo, Brazil.

Atallah, Z. K., Bae, J., Jansky, S. H., Rouse, D. I., and Stevenson, W. R. 2007. Multiplex real-time quantitative PCR to detect and quantify Verticillium dahliae colonization in potato lines that differ in response to Verticillium wilt. Phytopathology 97:865-872.

Botelho, L. S., Barrocas, E. N., Machado, J. C., and Martins, R. S. 2015. Detection of Sclerotinia sclerotiorum in soybean seeds by conventional and quantitative PCR techniques. J. Seed Sci. 37:55-62.

Brazil. 2009. Ministério da Agricultura, Pecuária e Abastecimento. Secretaria de Defesa Agropecuária. Regras para análise de sementes. MAPA/ACS, Brasília, Brazil.

Bustin, S. A., Benes, V., Garson, J. A., Hellemans, J., Huggett, J., Kubista, M., Mueller, R., Nolan, T., Pfaffl, M. W., Shipley, G. L., Vandesompele, J., and Wittwer, C. T. 2009. The MIQE guidelines: Minimum information for publication of quantitative real-time PCR experiments. Clin. Chem. 55:611-622.

Capote, N., Patrana, A. M., Aguado, A., and Sánchez-Torres, P. 2012. Molecular tools for detection of plant pathogenic fungi and fungicide resistance. Pages 151-202 in: Plant Pathology. C. J. Cumagun, ed. InTech, Rijeka, Croatia.

Carneiro, G. A., Matic, S., Ortu, G., Garibaldi, A., Spadaro, D., and Gullino, M. L. 2017. Development and validation of a TaqMan real-time PCR assay for the specific detection and quantification of Fusarium fujikuroi in rice plants and seeds. Phytopathology 107:885-892.

Chen, C., Zhao, W., Zhou, M., and Wang, J. 2010. High-throughput detection of Sclerotinia sclerotiorum from oilseed rape by TaqMan quantitative realtime PCR. Phytopathology 100:S23.
Choudhury, R. A., Garrett, K. A., Klosterman, S. J., Subbarao, K. V., and McRoberts, N. 2017. A framework for optimizing phytosanitary thresholds in seed systems. Phytopathology 107:1219-1228.

CONAB. 2019. Acompanhamento da safra brasileira de grãos, v. 7 Safra 2019/20 Terceiro levantamento. Companhia Nacional de Abastecimento, Brasília, Brazil.

Dias, M. D., Pinheiro, V. F., and Café-Filho, A. C. 2016. Impact of anthracnose on the yield of soybean subjected to chemical control in the north region of Brazil. Summa Phytopathol. 42:18-23.

Edwards Molina, J. P., Paul, P. A., Amorim, L., Silva, L. H. C. P., Siqueri, F. V., Borges, E. P., Campos, H. D., Venancio, W. S., Meyer, M. C., Martins, M. C., Balardin, R. S., Carlin, V. J., Grigolli, J. F. J., Belufi, L. M. R., Nunes Junior, J., and Godoy, C. V. 2018. Effect of target spot on soybean yield and factors affecting this relationship. Plant Pathol. 68:107-115.

Fittipaldi, M., Nocker, A., and Codony, F. 2012. Progress in understanding preferential detection of live cells using viability dyes in combination with DNA amplification. J. Microbiol. Methods 91:276-289.

Gadaga, S. J. C., Siqueira, C. S., and Machado, J. C. 2018. Molecular detection of Colletotrichum lindemuthianum in bean seed samples. J. Seed Sci. 40:370-377.

Galbieri, R., Araújo, D. C. E. B., Kobayasti, L., Girotto, L., Matos, J. N., Marangoni, M. S., Almeida, W. P., and Mehta, Y. R. 2014. Corynespora leaf blight of cotton in Brazil and its management. Am. J. Plant Sci. 5:3805-3811.

Gergerich, R. C., Welliver, R. A., Gettys, S., Osterbauer, N. K., Kamenidou, S., Martin, R. R., Golino, D. A., Eastwell, K., Fuchs, M., Vidalakis, G., and Tzanetakis, I. E. 2015. Safeguarding fruit crops in the age of agricultural globalization. Plant Dis. 99:176-187.

Giovanardi, D., Sutton, S. A., Stefani, E., and Walcott, R. R. 2018. Factors influencing the detection of Acidovorax citrulli in naturally contaminated cucurbitaceous seeds by PCR-based assays. Seed Sci. Technol. 46:93-106.

Glynn, N. C., and Edwards, S. G. 2010. Evaluation of PCR assays for quantifying seed-borne infection by Fusarium and Microdochium seedling blight pathogens. J. Appl. Microbiol. 108:81-87.

Godoy, C. V. 2015. Target spot. Pages 62-63 in: Compendium of Soybean Diseases and Pests. G. L. Hartman, J. C. Rupe, E. F. Sikora, L. L. Domier, J. A. Davis, and K. L. Steffey, eds. APS Press, St. Paul, MN.

Grabicoski, E. M. G., Jaccoud-Filho, D. S., Pileggi, M., Henneberg, L., Pierre, M. L. C., Vrisman, C. M., and Dabul, A. N. G. 2015. Rapid PCR-based assay for Sclerotinia sclerotiorum detection on soybean seeds. Sci. Agric. 72:69-74.

Grau, C. R., and Hartman, G. L. 2015. Sclerotinia stem rot. Pages 59-62 in: Compendium of Soybean Diseases, 5th Ed. G. L. Hartman, J. C. Rupe, E. J. Sikora, L. L. Domier, J. A. Davis, and K. L. Steffey, eds. APS Press, St. Paul, MN.

Guimarães, M. R. F., Siqueira, C. S., Machado, J. C., França, S. K. S., and Guimarães, G. C. 2017. Evaluation of inoculum potential of pathogens in seeds: Relation to physiological quality and DNA quantification by qPCR. J. Seed Sci. 39:224-233.

Hartman, G. L., West, E. D., and Herman, T. K. 2011. Crops that feed the world 2. Soybean - worldwide production, use, and constraints caused by pathogens and pests. Food Secur. 3:5-17.

Henneberg, L., Jaccoud Filho, D. S., Ruaro, L., and Panobianco, M. 2012. Efficiency of methods to detect Sclerotinia sclerotiorum in commercial soybean seed lots. Rev. Bras. Sementes 34:61-69.

Hoffman, D. D., Hartman, G. L., Mueller, D. S., Leitz, R. A., Nickell, C. D., and Pedersen, W. L. 1998. Yield and seed quality of soybean cultivars infected with Sclerotinia sclerotiorum. Plant Dis. 82:826-829.

Kavanagh, I., Jones, G., and Nayaby, S. N. 2011. Significance of controls and standard curves in PCR. Pages 67-78 in: PCR Troubleshooting and Optimization: The Essential Guide, 1st Ed. S. Kennedy and N. Oswald, eds. Caister Academic Press, Norfolk, U.K.

Koenning, S. R., and Creswell, T. C. 2006. Increased occurrence of target spot of soybean caused by Corynespora cassiicola in southeastern United States. Plant Dis. 90:974.

Lehner, M. S., Pethybridge, S. J., Meyer, M. C., and Del Ponte, E. M. 2017. Metaanalytic modeling of the incidence-yield and incidence-sclerotial production relationships in soybean white mold epidemics. Plant Pathol. 66:460-468.

Ma, Z., and Michailides, T. J. 2007. Approaches for eliminating PCR inhibitors and designing PCR primers for the detection of phytopathogenic fungi. Crop Prot. 26:145-161

Machado, J. C., Oliveira, J. A., Vieira, M. G. G. C., and Alves, M. C. 2001. Inoculação artificial de sementes de soja por fungos, utilizando solução de manitol. Rev. Bras. Sementes 23:95-101.

Machado, J. C., and Pozza, E. A. 2005. Razões e procedimentos para o estabelecimento de padrões de tolerância a patógenos em sementes. Pages 219-248 in: Sementes qualidade fitossanitária. L. Zambolim, ed. Universidade Federal de Viçosa, Viçosa, Brazil.

Mancini, V., Murolo, S., and Romanazzi, G. 2016. Diagnostic methods for detecting fungal pathogens on vegetable seeds. Plant Pathol. 65:691-703.

Milner, H., Ji, P., Sabula, M., and Wu, T. 2019. Quantitative polymerase chain reaction (Q-PCR) and fluorescent in situ hybridization (FISH) detection of soilborne pathogen Sclerotium rolfsii. Appl. Soil Ecol. 136:86-92.

Munkvold, G. P. 2009. Seed pathology progress in academia and industry. Annu. Rev. Phytopathol. 47:285-311.

Pellegrino, C., Gilardi, G., Gullino, M. L., and Garibaldi, A. 2010. Detection of Phoma valerianellae in lamb's lettuce seeds. Phytoparasitica 38:159-165. 
Ramiro, J., Ciampi-Guillardi, M., Caldas, D. G. G., Moraes, M. H. D., Barbieri, M. C. G., Pereira, W. V., and Massola, N. S., Jr. 2019. Quick and accurate detection of Sclerotinia sclerotiorum and Phomopsis spp. in soybean seeds using qPCR and seed-soaking method. J. Phytopathol. 167:273-282.

Rogério, F., Ciampi-Guillardi, M., Barbieri, M. C. G., Bragança, C. A. D., Seixas, C. D. S., Almeida, A. M. R., and Massola, N. S., Jr. 2017. Phylogeny and variability of Colletotrichum truncatum associated with soybean anthracnose in Brazil. J. Appl. Microbiol. 122:402-415.

Rogério, F., Gladieux, P., Massola, N. S., Jr., and Ciampi-Guillardi, M. 2019. Multiple introductions without admixture of Colletotrichum truncatum associated with soybean anthracnose in Brazil. Phytopathology 109: 681-689.

Rojas, J. A., Miles, T. D., Coffey, M. D., Martin, F. N., and Chilvers, M. I. 2017. Development and application of qPCR and RPA genus- and species-specific detection of Phytophthora sojae and P. sansomeana root rot pathogens of soybean. Plant Dis. 101:1171-1181.

Sanzani, S. M., Li Destri Nicosia, M. G., Faedda, R., Cacciola, S. O., and Schena, L. 2014. Use of quantitative PCR detection methods to study biocontrol agents and phytopathogenic fungi and oomycetes in environmental samples. J. Phytopathol. 162:1-13.

Schena, L., Abdelfattah, A., Mosca, S., Li Destri Nicosia, M. G., Agosteo, G. E., and Cacciola, S. O. 2017. Quantitative detection of Colletotrichum godetiae and C. acutatum sensu stricto in the phyllosphere and carposphere of olive during four phenological phases. Eur. J. Plant Pathol. 149:337-347.

Schena, L., Nbigro, F., Ippolito, A., and Gallitelli, D. 2004. Real-time quantitative PCR: A new technology to detect and study phytopathogenic and antagonistic fungi. Eur. J. Plant Pathol. 110:893-908.

Sievers, F., Wilm, A., Dineen, D., Gibson, T. J., Karplus, K., Li, W., Lopez, R., McWilliam, H., Remmert, M., Söding, J., Thompson, J. D., and Higgins, D. G. 2011. Fast, scalable generation of high-quality protein multiple sequence alignments using Clustal Omega. Mol. Syst. Biol. 7:539.

Sint, D., Raso, L., and Traugott, M. 2012. Advances in multiplex PCR: Balancing primer efficiencies and improving detection success. Methods Ecol. Evol. 3: 898-905.
Soares, S., Amaral, J. S., Oliveira, M. B. P. P., and Mafra, I. 2014. Quantitative detection of soybean in meat products by a TaqMan real-time PCR assay. Meat Sci. 98:41-46.

Sousa, M. V., Machado, J. C., Simmons, H. E., and Munkvold, G. P. 2015. Realtime quantitative PCR assays for the rapid detection and quantification of Fusarium oxysporum f. sp. phaseoli in Phaseolus vulgaris (common bean) seeds. Plant Pathol. 64:478-488.

Sousa, M. V., Siqueira, C. S., and Machado, J. C. 2016. Conventional PCR for detection of Corynespora cassiicola in soybean seeds. J. Seed Sci. 38:85-91.

Tomlinson, J. A., Boonham, N., Hughes, K. J. D., Griffin, R. L., and Barker, I. 2005. On-site DNA extraction and real-time PCR for detection of Phytophthora ramorum in the field. Appl. Environ. Microbiol. 71:6702-6710.

USDA. 2019. World Agricultural Production. Circular Series WAP 12-19. USDA/ FAS, Washington, DC

Vilanova, L., Usall, J., Teixidó, N., and Torres, R. 2017. Assessment of viable conidia of Monilinia fructicola in flower and stone fruit combining propidium monoazide (PMA) and qPCR. Plant Pathol. 66:1276-1287.

Walcott, R. R. 2003. Detection of seedborne pathogens. HortTechnology 13:40-47.

Walcott, R. R., Gitaitis, R. D., and Langston, D. B. 2004. Detection of Botrytis aclada in onion seed using magnetic capture hybridization and the polymerase chain reaction. Seed Sci. Technol. 32:425-438.

Willbur, J., McCaghey, M., Kabbage, M., and Smith, D. L. 2019. An overview of the Sclerotinia sclerotiorum pathosystem in soybean: Impact, fungal biology, and current management strategies. Trop. Plant Pathol. 44:3-11.

Wrather, A., Shannon, G., Balardin, R., Carregal, L., Escobar, R., Gupta, G. K., Ma, Z., Morel, W., Ploper, D., and Tenuta, A. 2010. Effect of diseases on soybean yield in the top eight producing countries in 2006. Plant Health Prog. 11:29.

Yang, H.-C., and Hartman, G. L. 2015. Anthracnose. Page 5 in: Compendium of Soybean Diseases and Pests. G. L. Hartman, J. C. Rupe, E. J. Sikora, L. L. Domier, J. A. Davis, and K. L. Steffey, eds. APS Press, St. Paul, MN.

Yang, H.-C., Haudenshield, J. S., and Hartman, G. L. 2015. Multiplex real-time PCR detection and differentiation of Colletotrichum species infecting soybean. Plant Dis. 99:1559-1568. 